\title{
Nicolas Poussin: Strides, Reverses and Backlogs - Some notes on the Cleveland drawing
}

\section{HENRY KEAZOR}

The festivities for the fourhundredth anniversary of Nicolas Poussin's birthday generated a whole wave of books, catalogues and articles, accompanying the exhibitions and colloquia. Ever since, our knowledge concerning the life and works of the French Master seems to have been extended further; in some domains, however, this understanding, if examined more closely, still appears to mark time, while in other fields there is even a tendency towards regression, when already obtained results are needlessly taken up for discussion again. All this is especially true of the Poussindrawing, which was purchased in December 1983 by the Cleveland Museum of Art (Fig. 1, 4); since its appearance at an exhibition in 1921, the sheet has been studied and questioned in particular by scholars as Anthony Blunt, Hillard Goldfarb and, recently, by Pierre Rosenberg together with LouisAntoine Prat. ${ }^{1}$ But while several points could be clarified, some already resolved problems have nevertheless been muddled again, and in the end a few aspects have remained obscure.

To start with the latter, there is the drawing on the recto-side of the sheet, depicting the scene of an Extreme Unction (Fig. 1). Blunt and Goldfarb rightly pointed out that this composition seems to be a very early sketch, which Poussin drew in preparation for the composition of the Extreme Unction (National Gallery of Scotland, Edinburgh; Fig. 2). ${ }^{2}$ This painting, executed in April 1644 , opened up the second cycle of the Seven Sacraments, ordered by Chantelou. ${ }^{3}$ But their proposition to read the drawing as the representation of the Death of the Virgin ${ }^{4}$ has recently been defied by Rosenberg and Prat who objected by pointing out that the dying person in the drawing seems to be male, not female. ${ }^{5}$ Since such questions about details, important as their consequences might be, hardly can be answered once and for all (the dying person in the drawing could, indeed, be interpreted as a female), other aspects have to be considered. Here, the attention should be focused on two points: first, the iconography of the scene, and secondly, its repetition in a copy of this drawing, today conserved at Bucarest (Biblioteca Academiei di Romania; Fig. 3).

Poussin himself described the composition of the Extreme Unction in a letter from April 25th, 1644 to Chantelou as a painting with "(...) diset figures d'hommes de fames d'enfants jeunes et vieus (...)". While the number of figures does not match exactly in the executed painting and in the Cleveland study, the children indeed do appear in both of them. But it is exactly this detail that makes the interpretation of the scene as the Death of the Virgin highly improbable since neither the written sources ${ }^{7}$ (which Poussin normally relied upon in such cases ${ }^{8}$ ) nor the iconographic tradition of this scene does provide the presence of children - on the contrary: their appearance would not only be unmotivated, it would seem unjustified. ${ }^{?}$

That the scene, depicted by Poussin in the drawing, does not appear to show the scene of the Death of the Virgin finally seems to find support also in the fact that the copy of the Cleveland drawing in Bucarest (Biblioteca Academiei di Romania; Fig. 3) clearly does not show a dying 


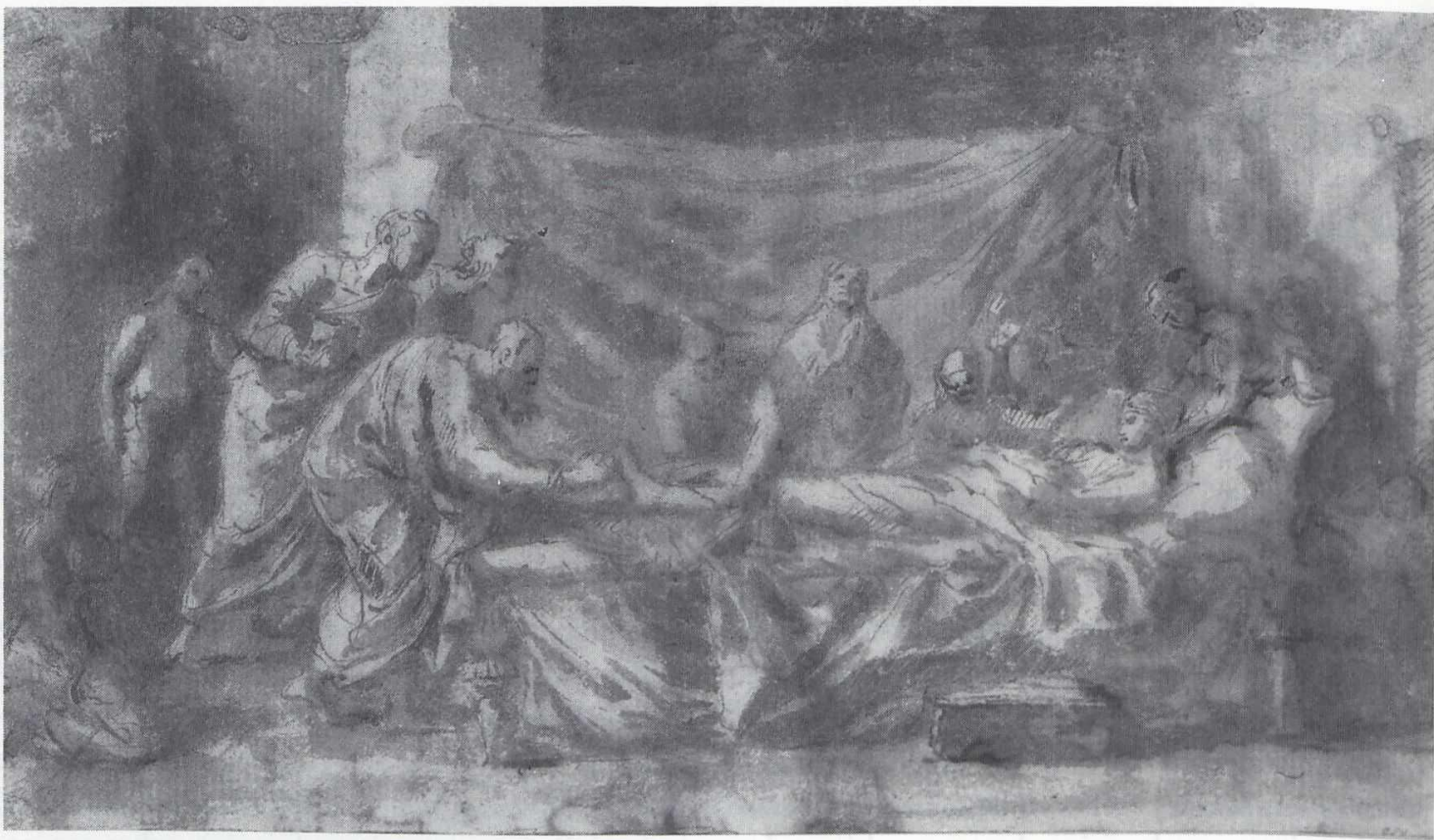

Fig. 1. Nicolas Poussin, recto side of the Cleveland drawing, showing the scene of the Extreme Unction. The Cleveland Museum of Art.

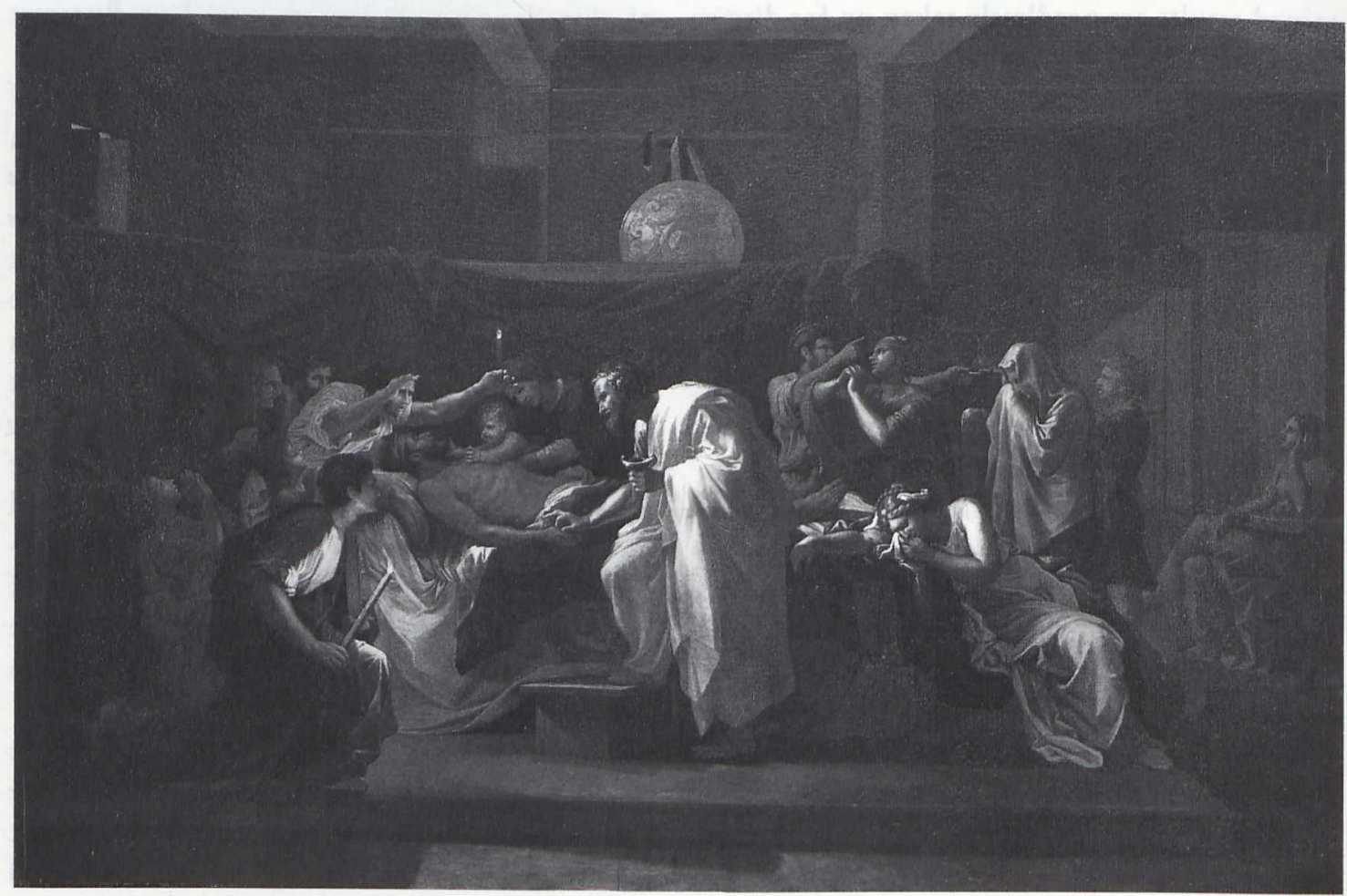

Fig. 2. Nicolas Poussin, Extreme Unction, from the second set of the Seven Sacraments for Chantelou. National Gallery of Scotland, Edinburgh. 


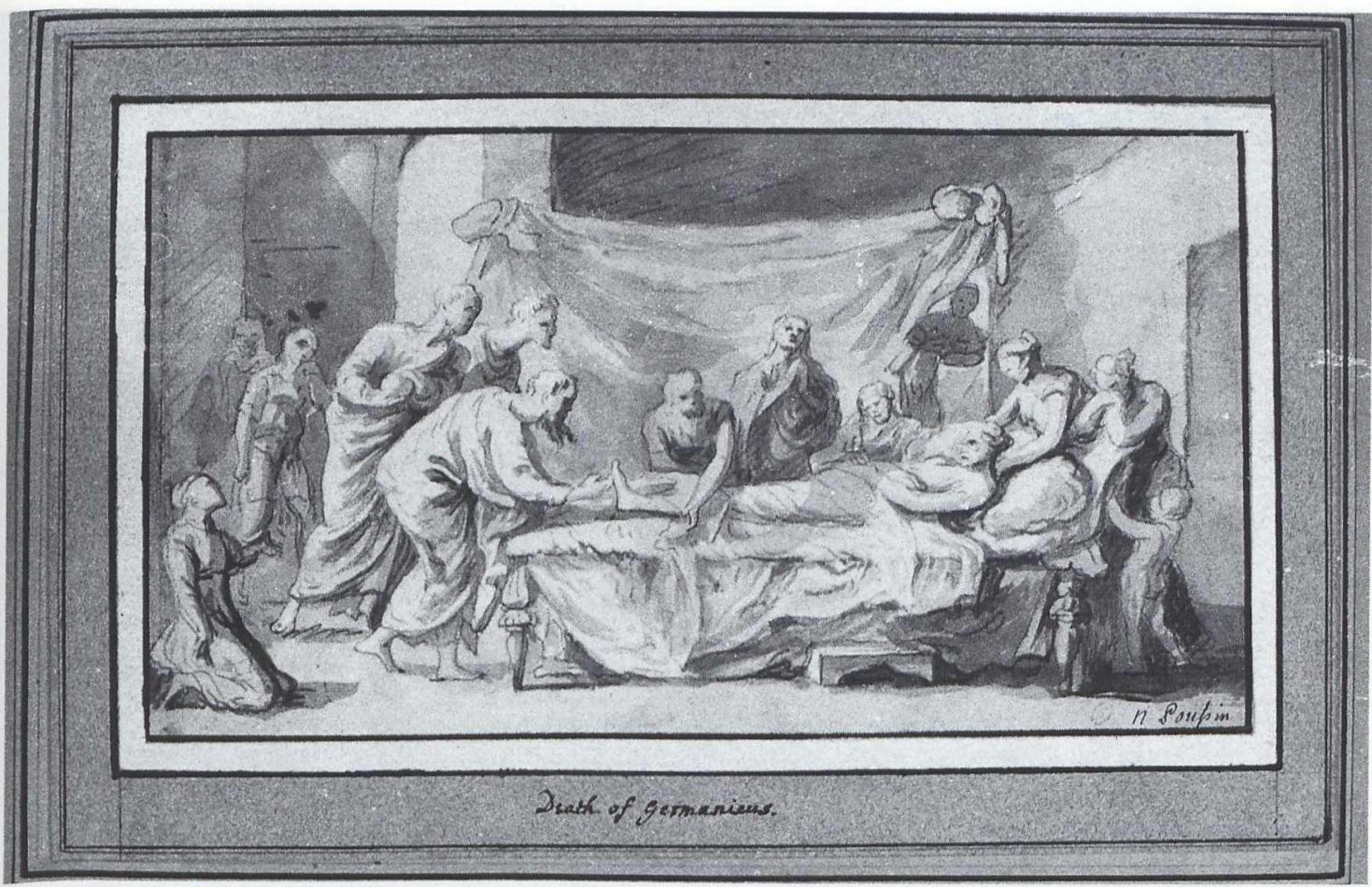

Fig. 3. Anonymous, Copy of the Extreme Unction scene from the Cleveland drawing. Bucarest, Biblioteca Academiei di Romania.

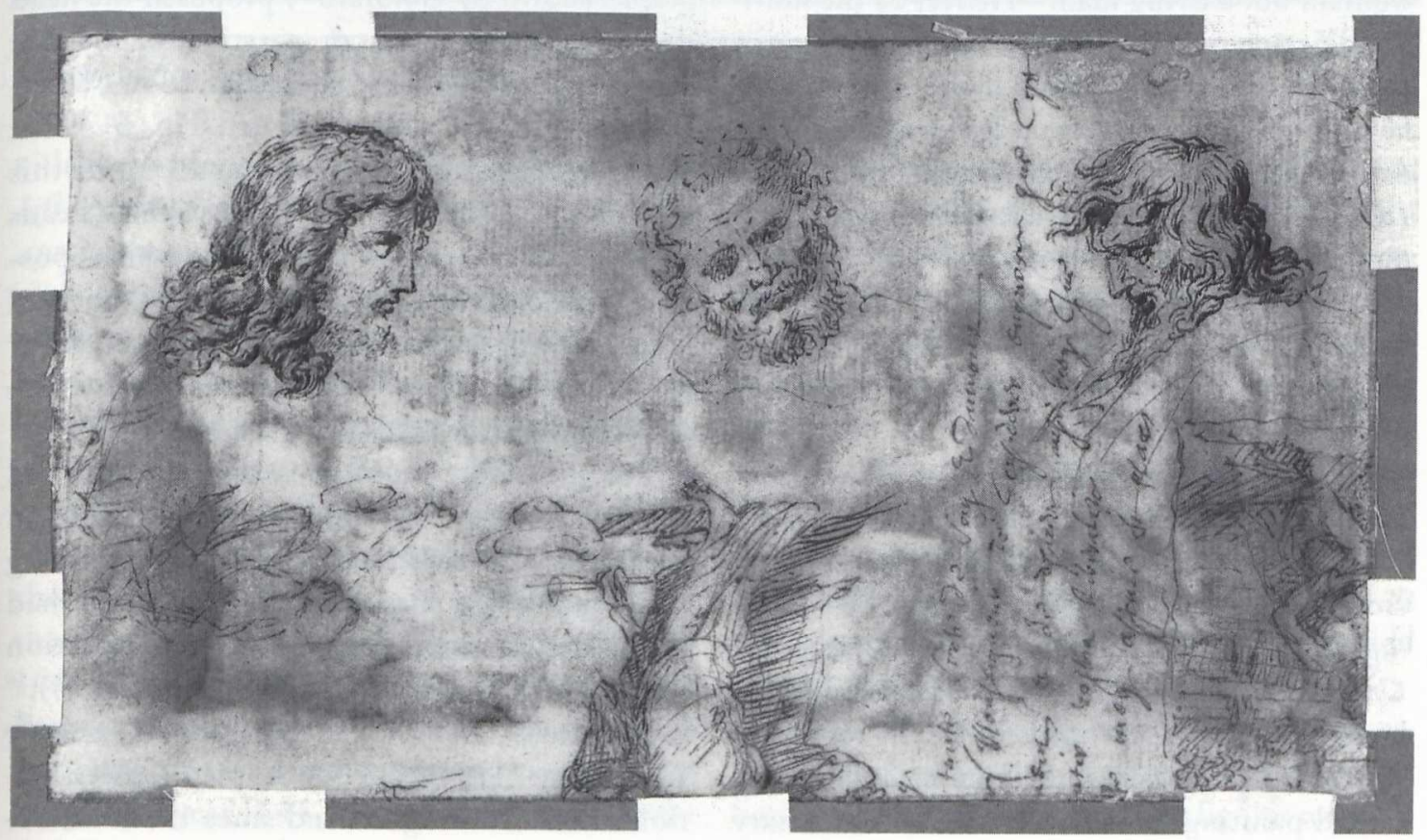

Fig. 4. Nicolas Poussin, verso side of the Cleveland drawing, showing several sketches and a letter draft. The Cleveland Museum of Art. 


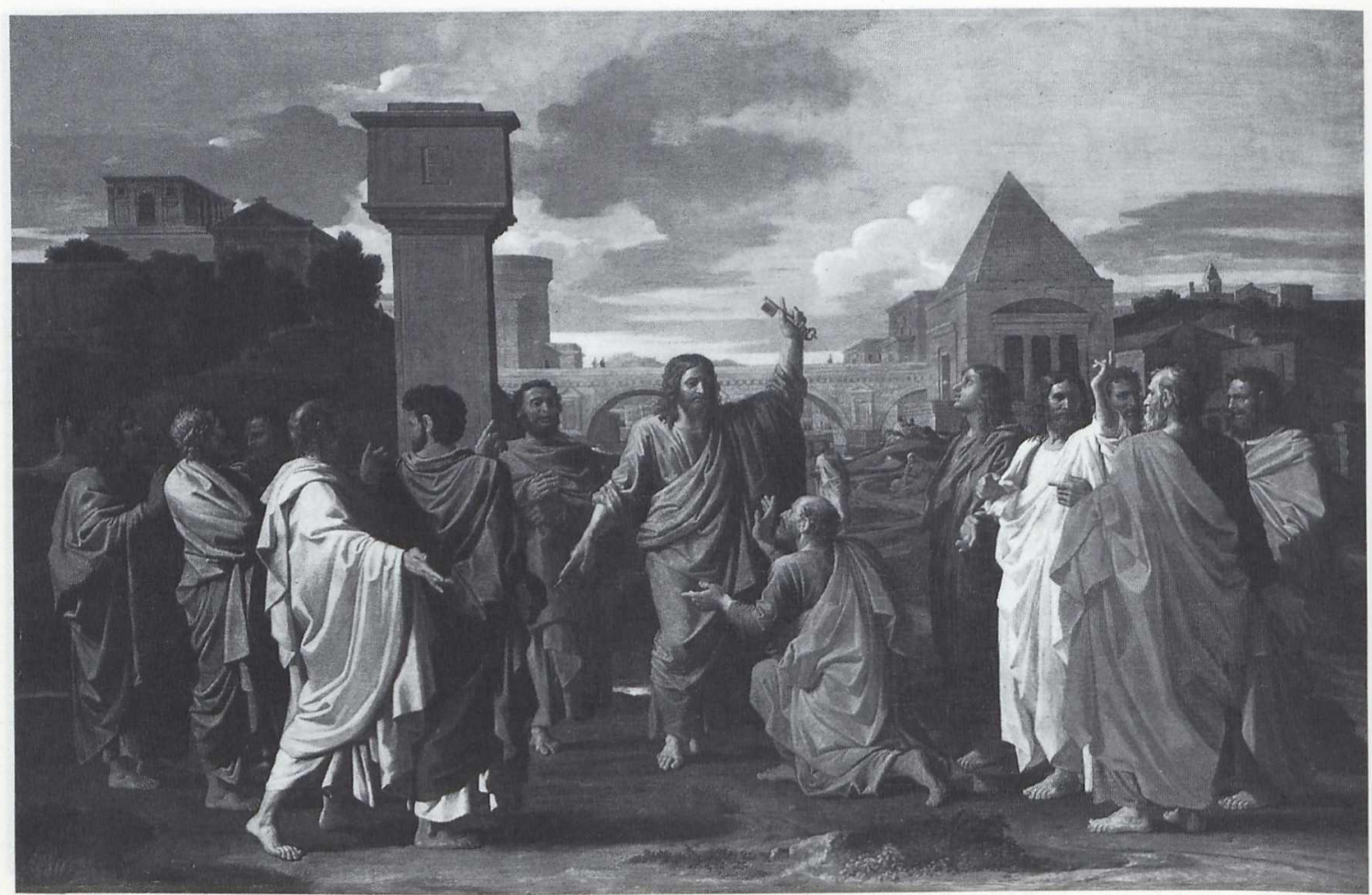

Fig. 5. Nicolas Poussin, Ordination, from the second set of the Seven Sacraments for Chantelou. Edinburgh, National Gallery of Scotland.

woman, but a dying man. ${ }^{10}$ Hence, be the moribund person on the Cleveland drawing a man or a woman, this change would in any case plead in favor of the assumption that the drawing simply depicts the early Christian antique rite of the Extreme Unction without taking on an iconography where gender questions matter - or otherwise, considering the Bucarest copy, Poussin apparently would be to blame for having created a highly misunderstandable version of the Death of the Virgin. ${ }^{11}$

Concerning the verso of the sheet (Fig. 4), Rosenberg and Prat recently created a certain confusion by stating that Anthony Blunt considered the three head studies as preparative drawings for the apostles in the second version of the Ordination (Edinburgh, National Gallery of Scotland; Fig. 5). ${ }^{12}$ Obviously, since there are no direct links between these studies and the executed painting, a correction seemed necessary. Hence, Rosenberg and Prat (perhaps being misguided by a parallel arrangement of two photo- graphs shown by Goldfarb ${ }^{13}$ ) proposed the head drawings to be made in preparation for the first version of the Baptism, painted in 1642 (Washington, National Gallery of Art; Fig. 6). ${ }^{14}$ But here one might still have problems accepting this view since no concrete link between these heads and the painting can be observed: to which apostle of the Baptism, for example, should the head seen in profile at the right side of the sheet, refer? And which disciple of Chist does the bearded face in the middle of the drawing represent? ${ }^{35}$

But the whole problem is instantly resolved when the text by Blunt himself is consulted and compared with the summary given by Rosenberg and Prat: while they claimed that Blunt had considered the head studies to be a preparation for the second version of the Ordination (Fig. 5), ${ }^{16}$ it was actually the first version (Rutland, Belvoir Castle; Fig. 7) Blunt cited as the pictorial destination of the drawings. ${ }^{17}$ And since the links between the drawn and the painted heads are quite obvious, he could even identify exactly the indi- 


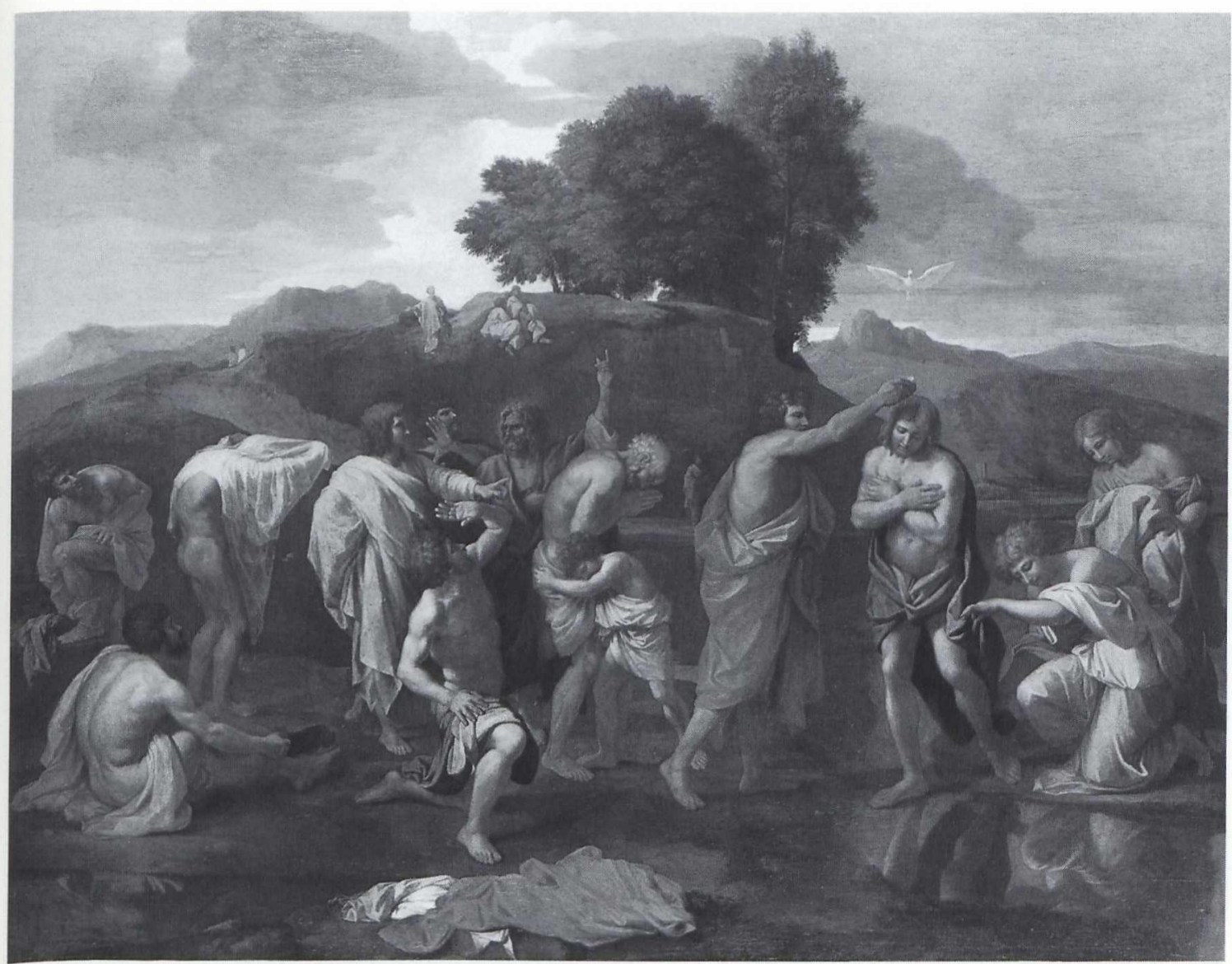

Fig. 6. Nicolas Poussin, Baptism, from the first set of the Seven Sacraments for Dal Pozzo. Washington, National Gallery of Art, Samuel H. Kress Collection.

vidual apostles prepared in the drawings: "on the left the head of Christ, in the middle that of the apostle behind the kneeling St. Peter, and on the right that of the sombre figure on the extreme right of the composition, who may perhaps be Judas." 18 Since these studies can thus be prooved to be linked neither with the second Ordination nor with the first Baptism but with the first Ordination, the execution of these heads has to be dated to about $1636 / 38 .{ }^{19}$ So, while the recto of the sheet was used by Poussin around March 1644 for the sketch of the Extreme Unction ${ }^{20}$ (the date 1643 usually applied is hardly convincing since Poussin decided definitely to paint the Seven Sacraments for Chantelou anew only at the beginning of the year 1644, instead of just copying the Dal Pozzo-version ${ }^{21}$ ), its verso is dated already around six or even eight years earlier. ${ }^{22}$
The same seems to be true of the span that separates the two sketches at the left and right border of the sheet from the written lines, interfering with the head of Judas (Fig. 4). Blunt has already demonstrated that the handwriting, readable when turning the sheet 90 degrees to the right, can be deciphered as a letter draft by Poussin where reference is made to the Surintendant des Bâtiments at Paris, Sublet de Noyers ( "Monseigneur"). ${ }^{23}$ Since de Noyers was forced to retire from his posts in 1643 and died in 1645, it seems plausible to date the draft to a period around $1643 / 44 .{ }^{24}$

If the sheet is now turned a further 90 degrees, three sketches become discernible: at the right border, a group of two struggling figures seems to fight for something lying on the ground and already seized by one of the adversaries (Fig. 4). 


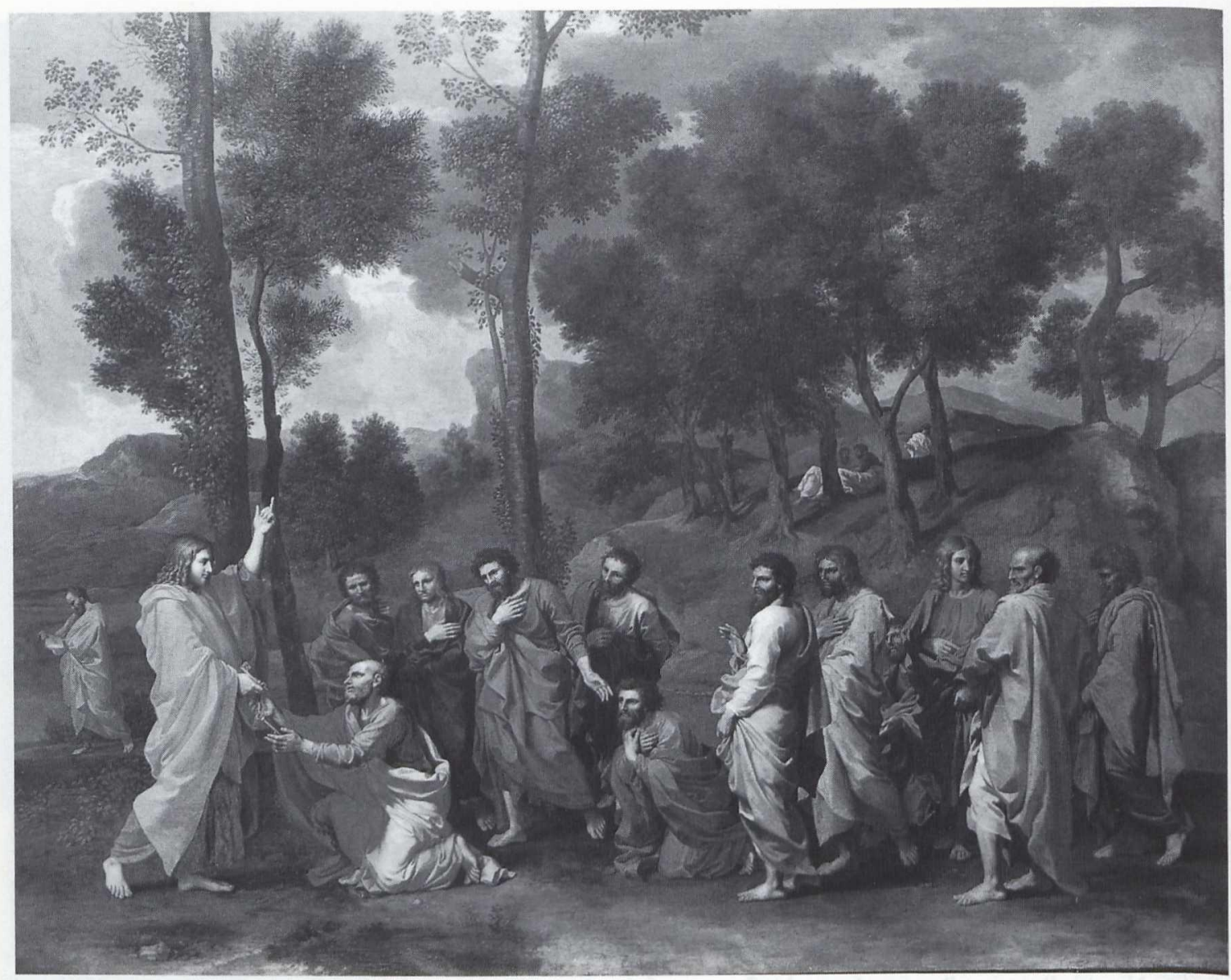

Fig. 7. Nicolas Poussin, Ordination, from the first set of the Seven Sacraments for Dal Pozzo, Rutland, Belvoir Castle.

While Blunt considered this to be related to the central sketch, Rosenberg and Prat ingeniously identified the two figures as a preparatory drawing for the group of crouching rivals in the Isrealites Gathering the Manna (Paris, Musée du Louvre; Fig. 8) from 1637/39. ${ }^{25}$

The sketch at the left border of the sheet, being cut almost entirely, was hitherto interpreted as a fragment of a study for one of the many Holy Families Poussin began to paint around 1648/ 49. ${ }^{26}$ According to this assumption, the torso of the drawn figure, carrying a child in its arm, passed for "St. Elizabeth holding St. John the Baptist with a river in the background". ${ }^{27}$ But unfortunately, this identification would have several odd consequences. To start with the date, it seems hardly likely that Poussin, who created comparable Holy Families with this river background only in and after 1650 (see e.g. The Holy Family with five figures: Paris, Musée du Louvre; ${ }^{28}$ Fig. 9), should have outlined this scene eleven years after he had drawn the closely related "Manna"group, and eight years after he had drafted the letter on the same sheet. But even if one would be inclined to believe in such a long time span, the figure itself in the sketch reveals several features, which - if considered as belonging to a St. Elizabeth - are quite bewildering.

First, there is the pose, showing her bending forward, the left knee contracted, the foot firmly posed on the apparently elevated ground as if she is about to mount from a hollow to a rise. In any case, this attitude is far away from the calm, quiet poise in which she is resting in the painting already cited, the Holy Family with five figures (Fig. 9). 


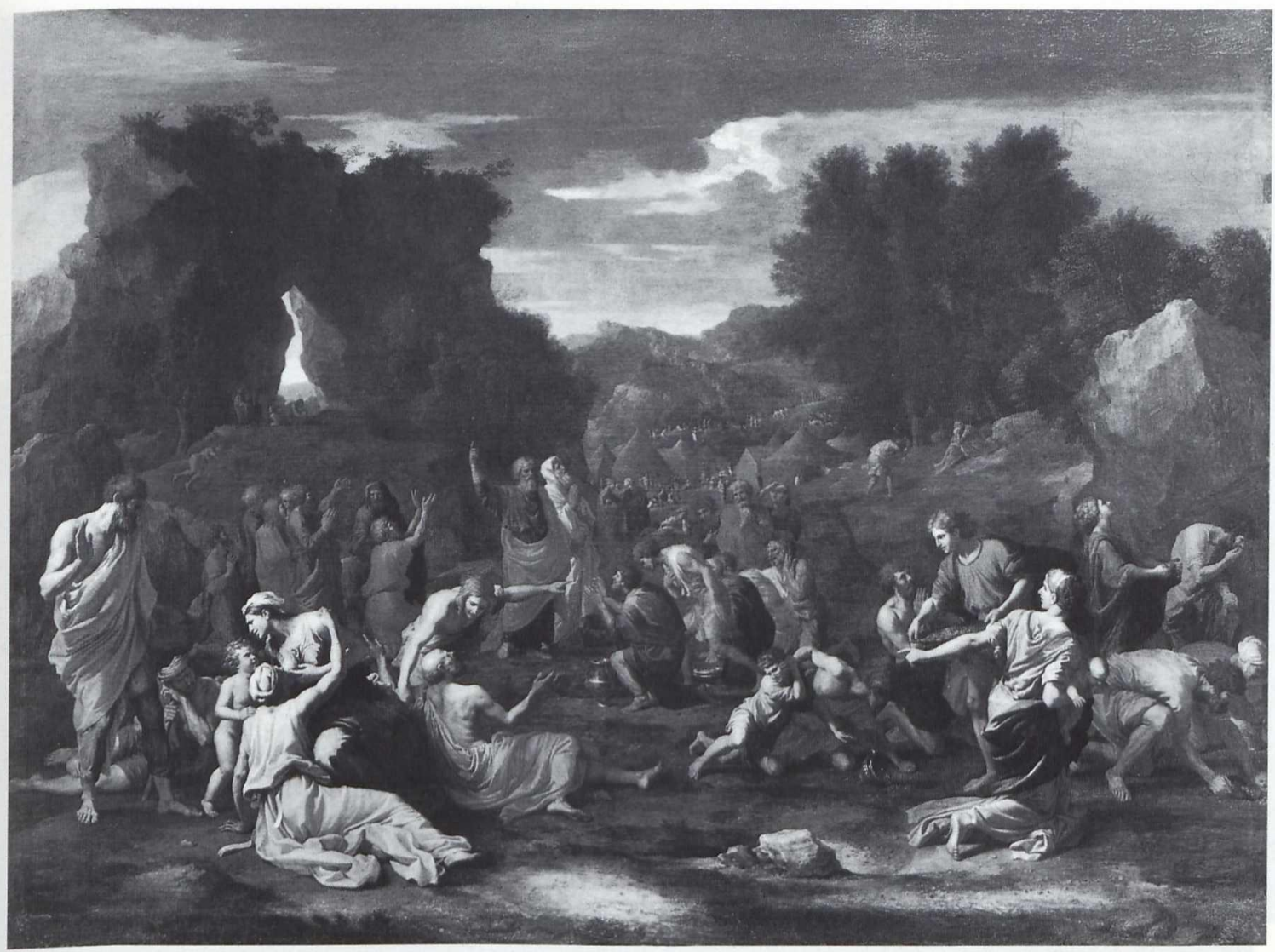

Fig. 8. Nicolas Poussin, The Israelites Gathering the Manna. Paris, Musée du Louvre.

There, St. Elizabeth supports the little St. John, sitting on her lap, while the drawing shows a figure that actually carries a child in its arms a pose rather unusual for the iconography of these saints and, if considered as really representing St. Elizabeth and St. John, shown in a manner that has been appropriately described as "gauche." ${ }^{29}$

But first of all the garments, worn by the figure, arouse great doubts since they seem totally incompatible with the representation of a St. Elizabeth: the fact that the breast is exposed and the arms are left naked seems to plead in favour of the assumption that here the same kind of discussion applies, which has already been exited in the case of the recto scene. But while the question there - about the male or female figure - eventually had to be left unsettled, here an answer is near at hand. If the sketch is seen together with Poussin's preparatory drawing for his Finding of Moses, executed in 1638 (Berlin, Kupferstichkabinett;
Fig. 10$)^{30}$ as well as the painting itself (Paris, Louvre; Fig. 11), ${ }^{31}$ it becomes obvious that the figure is not a sketch of St. Elizabeth, but of the servant in the "Moses"-scene who hands the newfound baby to the Egyptian women, waiting at the slightly elevated bank slope. While the preparatory drawing at Berlin with its fluid and still quite blurred strokes apparently served to fix only the general composition of the scene for Poussin, the today mutilated sketch on the verso of the Cleveland sheet must once have been executed as a more detailed preparation for it. So, while the background in the Berlin sketch is only indicated very coarsely and faintly, the Cleveland drawing already provides, clearly recognizable, the river backdrop with the two tiny figures on the other side of the bank (and even their reflexion in the water) as they appear also in the finished painting.

It is now very seductive to speculate that the hardly readable sketch in the middle of the verso 


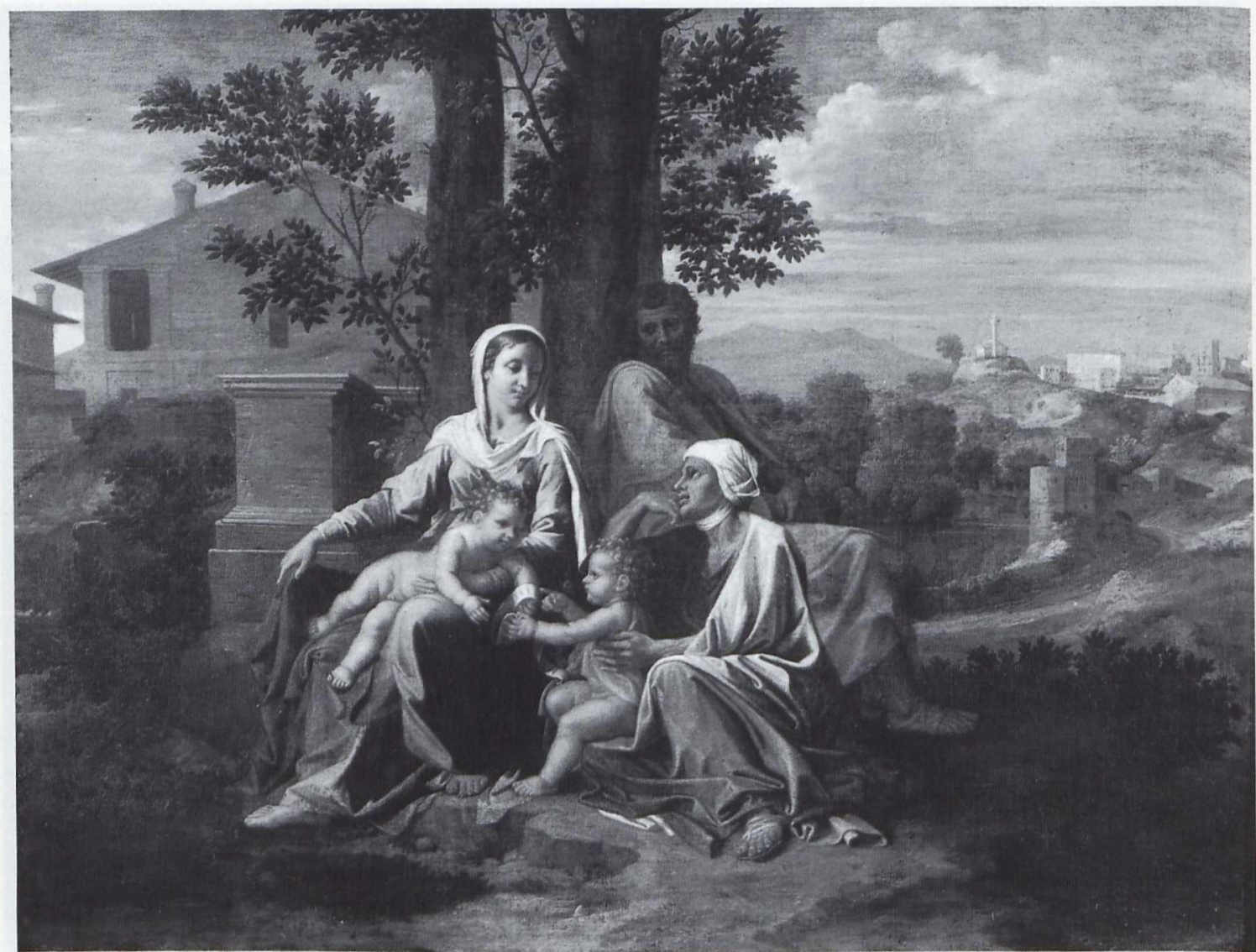

Fig. 9. Nicolas Poussin, The Holy Family with five figures. Paris, Musée du Louvre.

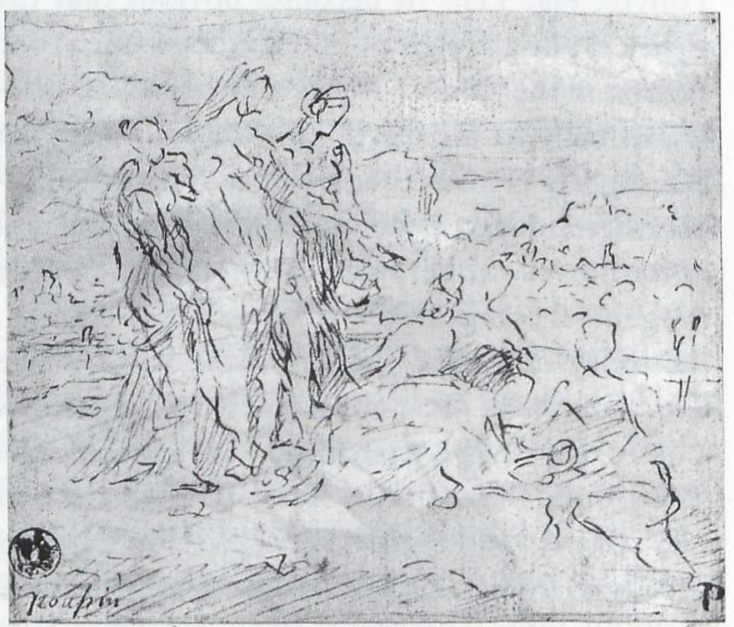

Fig. 10. Nicolas Poussin, Preparative sketch for the Finding of Moses. Berlin, Kupferstichkabinett. might also be linked to this "Moses"-scene, preparing e.g. the lower part of the maidservant's body with the pleats of her garment, while the heavy shadow in the background could thus be interpreted as the outlines of Pharaoh's daughter, leaning on the shoulder of the maidservant. But since the upper part of the composition is missing and parts of the drawing have been rubbed out by Poussin himself with the help of vigorous hatchings, caution and reserve in assigning the sketch to a known composition seems to be appropriate. $^{32}$

Nevertheless, the assumption might be permitted that this composition also dates from the end of the 1630s since both the "Manna"-drawing at the right and the "Moses"-drawing on the left are dating from around $1637 / 38$, it seems reasonable to think of the central drawing as being executed during a project in about the same period. 


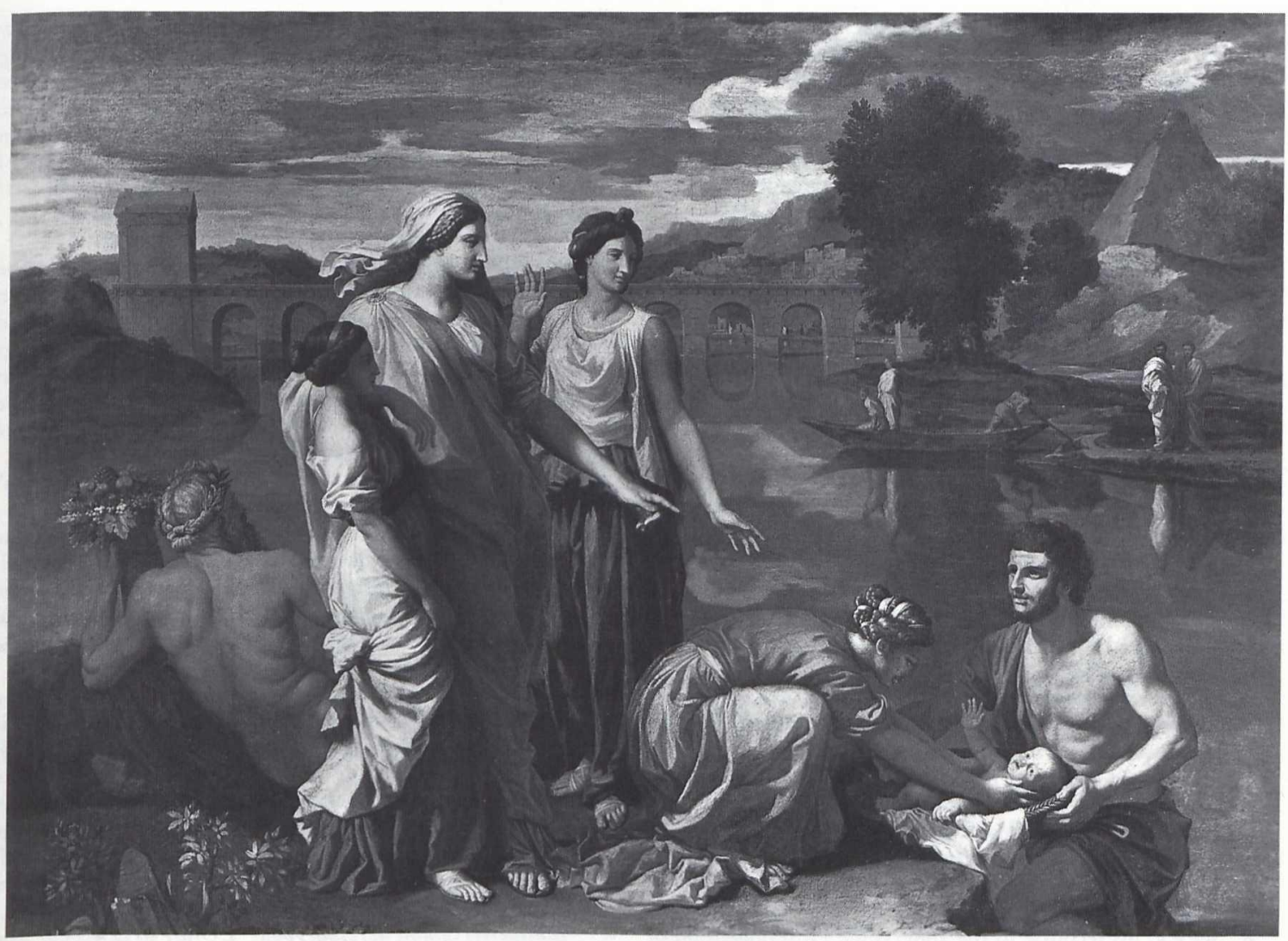

Fig. 10. Nicolas Poussin, The Finding of Moses. Paris, Musée du Louvre.

Moreover, the three heads, on the other half of the sheet, are stemming from around this time. Only in 1643/44, six or seven years after he had drawn all these sketches, Poussin used the space left and drafted the already cited letter. Shortly afterwards he might have cut the sheet, on the blank backside of which he then drew one of the very first sketches for the Extreme Unction. ${ }^{33}$ So, the Cleveland sheet, showing sketches for works of the years $1636 / 38$ and $1643 / 44$, only matches projects Poussin executed in Rome: on the other hand, his stay in Paris during the period 16401642 does not seem to have left any trace. One may deduce from this conspiciuous chronological gap that the sheet belonged to the bulk of drawings Poussin left behind in Rome ${ }^{34}$ when he reluctantly went to Paris in 1640 , hoping to return as soon as possible.

But Poussin associated to paintings stemming from the different periods of around 1638 and
1644 not only on drawing sheets. In his already cited letter to Chantelou with the description of the intended composition for the Extreme Unction, he also referred this Sacrament-painting, then still on the easel, to the "Manna", comparing both pictures: "le tableau sera enuiron de la grandeur de vostre manne, mais de plus belle proportion." ${ }^{\text {'5 }}$

So, in Rome, being free from the pressures laid upon him in Paris, ${ }^{36}$ he had promised Chantelou already in 1643 to do his very best again: "(...) Je me sens bien d'humeur à faire quelque chose de bon. ${ }^{37}$ And, in fact, he kept his promise.

\section{Notes:}

1. Walter Friedländer/Anthony Blunt, The Drawings of Nicolas Poussin, Vol. I, London 1939, p. 49, No. A 22; Anthony Blunt, "Further newly identified drawings by Poussin and his followers", in: Master Drawings, XVII, 1979, p. 119 146; Hilliard Goldfarb, "A Highly Important Poussin Acquisition and Chantelou's 'Seven Sacraments' Series”, in: 
The Bulletin of The Cleveland Museum of Art, LXXI, October 1984, p. 290 - 299; ibid., From Fontainebleau to the Louvre: French Drawing from the Seventeenth Century, Exp.Cat., The Cleveland Museum of Art 1989, p. 44 - 47, No. 16, Pierre Rosenberg/Louis-Antoine Prat, Nicolas Poussin 1594 - 1665: Catalogue raisonné des dessins (= R.-P.), Milan 1994, Vol. I, p. 192 - 195, No. 105 and Vol. II, p. 822, No. R 204.

2. For the painting see Pierre Rosenberg, Nicolas Poussin: 1594 - 1665, Exp.Cat., Paris, Grand Palais 1994, p. 314, No. 107.

3. Blunt (1979), p. 125; Goldfarb (1984), p. 291 and Goldfarb (1989), p. 44. In contradiction to Blunt and Goldfarb, Rosenberg (1994), p. 244, No. 64 erroneously claims that the drawing belongs to the development of the first version of the "Extreme Unction" - but in R.-P., I, p. 192, No. 105 he rightly assorts it to the second version. Poussin, as documented in a letter to Chantelou, started to work upon the second series of the "Sacraments" in April the 14th, 1644 (see: Ch. Jouanny, Correspondance de Nicolas Poussin, in: Archives de l'art français, N.P., Tome V, Paris 1911, p. 264).

4. Blunt (1979), p. 125s.; Goldfarb (1984), p. 292; Goldfarb (1989), p. 44 , No. 16.

5. R.-P., I, p. 192 , No. 105.

6. Jouanny, p. 266, No. 107: the whole sentence runs: "Le dit tableau contiendra diset figures d'hommes de fames d'enfants jeunes et vieus une partie desquelles se consomment en pleurs et les autres prient dieu pour le moribond."

7. See Jacobi a Voragine, Legenda Aurea (ed. by Th. Graesse), Dresden/Leipzig 1846, chapter CXIX (114), p. 504ss: "De assumatione beatae Mariae Virginis"; for a presentation and analysis of the early apocryphal sources see Martin Jugie, La mort et l'Assomption de la Sainte Vierge, Vatican 1944, chapter III.

8. See e.g. his recourse to the apogryphic Protevangelium of James $(8,2-9,3)$ for the paintings of the "Matrimony" for both the Dal Pozzo as well as for the Chantelou-set of the "Seven Sacraments"; for these paintings see Rosenberg (1994), p. 243 , No. 63 and p. 320, No. 113.

9. See e.g. the school-making painting by Carlo Saraceni of a "Death of the Virgin" (Rome, S. Maria della Scala: Cappella Laerzio Cherubini) from $1610 / 1620$, which not only produced a whole series of repetitions due to Saraceni's shop as well as copies (also because of the wide-spread engraving by Jean Le Clerc from 1619), but also clearly influenced creations like the drawing at Hovingham Hall (Sir Marcus Worsley), still bearing an attribution to Poussin. In neither of this scenes, children ever appear. Only in scenes of the procession, conducting the already dead Virgin to the cemetery, children are sometimes inserted, but serving here only the official function of acolytes: see for this e.g. the painting by Ferraù Fenzoni (Ravenna, Chiesa di Sant' Apollinare Nuovo), dated to 1612 (when actually depicting the scene of the Virgin's death - as in his painting in the Pinacoteca in Faenza -, Fenzoni, too, does not show any children). In the Cleveland drawing, however, the children are merely shown in an anecdotical manner as mourning family (?) members. For the Saraceni-painting and its fortune see Anna Ottani Cavina, Carlo Saraceni, Milan 1968, p. 118ss., No. 69 and Jacques Thuillier, Claude Lorrain e i pittori lorensi in Italie nel XVII secolo, Rome 1982, p. 92s., No. 5; for the Hovingham Hall drawing see R.-P., I, p. 4s., No. 1. Concerning Fenzoni's Ravenna painting see Nadia Ceroni/Giordano Viroli, Biblia Pauperum - Dipinti dalle diocesi di Romagna 1570 - 1670, Ravenna, Museo Nazionale, 1992, p. 127s., No. 37; for the picture at Faenza see Antonio Archi, La pinacoteca di Faenza, Faenza 1957 , p. 29 s. and p. 43.
10. Hence, it seems to be in accordance with Poussin's already cited description of the intended scene, defining the dying person ( "le moribond") as male. Interestingly enough, Horace Walpole as one of the previous owners indeed identified the dying man as "Germanicus" and called the scene with an inscription on the mount of the drawing as the "Death of Germanicus". For the Bucarest drawing see Blunt/ Friedländer, V, p. 90; Blunt (1979), p. 124 and p. 143s., note 15; R.-P., I, p. 192 and II, p. 822, R 204.

11. The same can be put forward against the hypothesis that the scene could represent a "Death of St. Anne"; here - given the fact that the little Jesus can be present - children sometimes do indeed appear: see for example the paintings by Quentin Metsys at the Royal Museum of Fine Arts at Brussels or by a follower of Carlo Maratta, once at the Collezione Sfano at Cagliani (Photo at the Photothek of the Kunsthistorisches Institut, Florence).

12. R.-P., Vol. I, p. 194, No. 105. Concerning the "Ordination" see Rosenberg (1994), p. 318, No. 111.

13. See the two photographs of the head drawings and the "Baptism", shown side by side in Goldfarb (1984), p. 292, Fig. 3 and 4: however, Goldfarb never intended this to be an instructive comparison since he later related not the $\mathrm{Dal}$ Pozzo-"Baptism", but the Chantelou-"Ordination" to these heads in Goldfarb (1989), p. 47, No. 16.

15 The same questions have to be asked considering the proposal formulated by Goldfarb (see note 13 above): his hypothesis that Poussin drew the heads as "first thoughts for the second 'Ordination'" being at the same time perhaps inspired by an unknown Raphael-drawing, does not get down to the fact that the heads on the drawing are quite close in physiognomy and pose to those in the first "Ordination", but totally strange to those in the second version.

16. R.-P., I, p. 194: "Quant aux trois têtes d'apôtres, Blunt les a considérées comme des études pour 'L'Ordre' de la seconde série (...)".

17. Blunt (1979), p. 126: "The three heads are studies for the 'Ordination' in the first series of Sacraments (...). "Concerning this painting see Rosenberg (1994), p. 247, No. 67.

18. Blunt (1979) as cited in the note above.

19. Except for the late "Baptism", finished and delivered ac cording to epistolary references in Spring 1642 (see Jouanny, p. 124 and p. 153: "un Battesimo di Christo composto di 13 figure principali"), the dates of the other "Sacraments"paintings for Dal Pozzo are still a hotbed for debates: nevertheless, since opinions concerning the "Ordination" are usually oscillating around $1636 / 38$, this period may be accepted as quite safe; for the date of the "Ordination" see e.g. Doris Wild, Nicolas Poussin - Leben, Werk, Exkurse, Zurich 1980, Vol. II, p. 75, No. 76; Richard Verdi, Nicolas Poussin: 1594-1665, Exp.Cat., London, Royal Academy of Arts 1995 , p. 225 , No. 39.

20. See note 3 .

21. In a letter from January $7 \mathrm{th}, 1644$ Poussin still tells about his efforts to find someone capable of copying his Dal Pozzo paintings for Chantelou: see Jouanny, p. 239, No. 97. Then, five days later, he proposes to copy the pictures himself or to paint a set of new pictures: Jouanny, p. 245 , No. 100. Finally, in March 1644 he seems to have repeated this offer of new versions to a now accepting Chantelou: Jouanny, p. 256ss., No. 104. Nevertheless, Blunt (1979), p. 128 speculates that Poussin, foreboding his later suggestion to Chantelou, might have begun several sketches long before that date. Goldfarb (1984), p. 292 and Goldfarb (1989), p. 44, No. 16 adopts this hypothesis, while R.-P., I, p. 194 , No. 105 repeats the date of 1643 without discussing it.

22. Blunt (1979), p. 128 very cautiously dates the head drawings to "before 1640"; Goldfarb (1989), p. 47, No. 16 on 
the basis of the assumption that the heads are drawn in preparation for the second "Ordination" seems to plead for a date around 1647, while R.-P., p. 318, No. 111, thinking that they are studies for the first "Baptism", are proposing 1642 ; concerning the dates of these two paintings see notes 12 ("Ordination") and 19 ("Baptism").

23. Blunt (1979), p. 128; he further claims that the letter should have been addressed to Chantelou: a hypothesis, which sounds possible but remains unfounded by any argument. R.-P., I, p. 194 are erroneously reporting de Noyers as being deceased in 1654 instead as - correctly - in 1645.

24. Blunt (see note above) claims the letter to be written before the end of 1643 "since references to De Noyers after his final retirement are rare"; it is in fact true that Poussin names him in his known letters, written in 1643, twice as often as in those written one year later. Statistically spoken it is nevertheless difficult to judge the five references in the 1644letters as "rare" against the nine namings in the 1643correspondence (see for 1643: Jouanny, Nos. 83, 84, 87, $88,89,92,93,95,96$; for 1644 see: Jouanny, Nos. 97, 101, $105,112,120)$. For 1645 , there is only one reference in April (Jouanny, p. 301, No. 121).

25. Blunt (1979), p. 127; R.-P., I, p. 194, No. 105. Goldfarb (1989), p. 47, No. 16 thought them to be a study for a (later deleted) group in Poussin's first version of "Moses Striking the Rock" (Edinburgh, National Gallery of Scotland) from 1634 - for this painting see Anthony Blunt, The Paintings of Nicolas Poussin, London 1966, p. 19, No. 22; for the "Isrealites Gathering the Manna" see Rosenberg (1994), p. 262ss., No. 78. On the evidence of a letter, cited by Félibien, as well as by Félibien's report, it becomes clear that Poussin started to work on the "Manna" in 1637; he delivered the painting in 1639. For the cited letter see also Jouanny, p. 5.

26. Blunt (1979), p. 127 ; R.-P., p. 192 , No. 105 ,

27. Blunt (1979), p. 127.

28. See for this Gilles Chomer/Sylvain Laveissière, Autour de Poussin, Exp.Cat. Paris, Louvre, 1994, p. 74, No. 18.

29. R.-P., I, p. 193, No. 105 are judging the pose, in which the child is resting in the arm of the figure, as "gauche replie".

30. R.-P., p. 260s., No. 134.

31. For the painting, executed in 1638 according to Félibien, see Rosenberg (1994), p. 281 ss., No. 92 and Verdi (1995), p. 213 s., No. 35 .

32. Blunt (1979), p. 126s. thought the sketch to be related to a "Pasiphae" composition by Jean Lemaire; against this hypothesis see R.-P., p. 194, No. 105, who have already difficulties in recognizing the bull, which is, according to Blunt, discernible behind Pasiphae. Concerning Lemaire's two "Pasiphae"-paintings see Maurizio Fagiolo dell'Arco,
Jean Lemaire - pittore "antiquario", Rome 1996, No. 20, p. 176 and No. 54, p. 214 s.

33. Blunt (1979), p. 128 thinks that it is due to an owner that the sheet was cut, but it could have been also Poussin himself, who cut it to the present shape.

34. See e.g. his letter to Cassiano Dal Pozzo from the 27th June, 1642 (Jouanny, p. 166) where he explicitly refers to one of these drawings.

35. Jouanny, p. 267, No. 107.

36. See the letter from April 7th, 1642 written at Paris to Chantelou: "Le Génie du Poussin veut agir si librement que je ne veux pas sellement lui indiquer ceque celui du Roy désire du sien": Jouanny, p. 133, No. 59.

37. Letter from September 23th, 1643: see Jouanny, p. 215, No. 88.

\section{Summary}

In 1983 the Cleveland Museum of Art acquired a drawing, showing several sketches by Nicolas Poussin on its recto as well as on its verso. Since there have been some errors and confusions regarding this drawing in the last time (first of all, due to the publications accompanying the celebrations of Poussin's 400th birthday), the aim of this article is to sum up, to (where necessary) correct and, finally, (where possible) to extend the state of research on this sheet. Hence, it is shown that the iconographic identification of the recto-scene, proposed by some authors, has to be reconsidered. Furthermore, some errors concerning the context and the date of some of the versosketches are indicated and corrected. Finally, it can be shown that one drawing (likewise on the verso of the sheet) was not - as hitherto thought - intended to prepare a "Holy Family" but a "Moses"-scene. On the base of these findings, considerations upon the chronological and biographical implications of the whole sheet are submitted as a conclusion.

Henry Keazor

Kunsthistorisches Institut,

Via Giuseppe Giusti 44

1-50121 Florence

Italy 